\title{
SEMMIT RÓLUNK NÉLKÜLÜNK! - TANULÁSI MOBILITÁSSAL AZ INKLUZIVITÁS FELÉ
}

\author{
KOVÁCS GABRIELLA
}

\author{
Budapesti Müszaki Egyetem, Idegen Nyelvi Központ
}

Maurice Devlin, Søren Kristensen, Ewa Krzaklewska \& Magda Nico (eds): Learning Mobility, Social Inclusion and Non-Formal Education. Access, Processes and Outcomes. (Youth Knowledge, \#22/.) Strasbourg, 2017. Council of Europe. 202 p. ISBN: 978-92-871-8444-3

A 2017-ben kiadott kötet a Youth Partnership program keretében szerkesztett Youth Knowledge nevü sorozat kiadványa. A sorozat 2013-ban már megjelentetett egy kötetet ugyanebben a témában (Learning Mobility and Non-Formal Learning in European Contexts. Policies, Approaches and Examples). Mivel a gazdasági válság és annak következményei (munkanélküliség, kirekesztettség, társadalmi-gazdasági marginalizálódás, diszkrimináció, szegénység) legérzékenyebben a fiatalokat érintette, a szerkesztőbizottság fontosnak érezte, hogy ezúttal az inkluzivitást is tárgyalja. A legújabb értékelő kutatások alapján ugyanis a tanulói mobilitás hathatós eszköze lehet a felzárkóztatásnak, az inkluzív társadalom megteremtésének, amennyiben a valóban rászorulók is esélyt kapnak a bekapcsolódásra, és amennyiben megfelelően történik a bevonásuk.

A kötet elött érdemes szót ejteni egy kicsit bővebben magáról a programról is, hiszen az egész sorozat legfőbb távlati célja, hogy mindenki egyenlö eséllyel férjen hozzá az általa nyújtott lehetőségekhez, amihez viszont elengedhetetlen a keret- rendszer ismerete. A Youth Partnership az Európai Bizottság és az Európa Tanács által 1998-ban létrehozott együttmüködési program, melynek átfogó célja a partnerintézmények bevonásával a két európai intézmény ifjúságorientált tevékenységei közötti szinergiák előmozdítása és mindkét intézmény érdeklődésére számot tartó témák kidolgozása, ezek támogatása. Minden tevékenységében prioritást élveznek a kommunikációs és tájékoztatási szempontok, hogy az eredmények minél szélesebb körhöz eljuthassanak. Földrajzilag magában foglalja az Európai Unió és az Európa Tanács tagjait és az Európai Kulturális Egyezmény más aláíró államait. Számos szervezet vesz részt az együttmüködésben, mint például az Európai Ifjúsági Fórum, az Erasmus+ ifjúsági irodái, a SALTO képzési és együttműködési erőforrásközpont, az Európai Ifjúsági Információs és Tanácsadó Ügynökség (ERYICA), az Eurodesk, az Európa Tanács Európai Ifjúsági Kormányközi Bizottsága (CDEJ), illetve egyéb partnerek.

Magyarországon a Tempus Közalapítvány képviseli az ERASMUS+ program 
nemzeti irodáját, honlapjukat minden mobilitásra vágyó fiatalnak és velük foglalkozó felnőttnek érdemes tanulmányoznia, mert a program ifjúsági fejezete az, amely a legtöbb mobilitás lehetőségét kínálja. A fiataloknak és ifjúságsegítőknek szóló projekteken kívül az Erasmus+ program az európai önkéntes szolgálat nagyszabású projektjei, a stratégiai partnerségek és a kapacitásfejlesztés az ifjúsági területen, valamint a fiatalok és az ifjúsági területen döntéshozó személyek találkozói pályázati kategóriák keretében is támogatja a fiatalok mobilitását. ${ }^{1}$

Kutatók számára érdekes lehet még az ún. RAY kutatás (Research-based Analysis and Monitoring of Youth in Action $^{2}$ ), amely az Erasmus+ ifjúsági elödprogramjának, a Fiatalok Lendületben programnak az empirikus kutatáson alapuló, nemzetközi vizsgálata. A kutatások európai és hazai szinten a jelenleg futó programciklusban (2014-2020) is folytatódnak.

Jelen kötet mind a téma szakértői, mind a területre újonnan érkezők számára ajánlható. Fontos kiemelni, hogy a föbb fogalmakat és kérdéseket a szerzők az európai ifjúságpolitika és -gyakorlat jelenlegi (2017) fejleményeinek fényében magyarázzák. Míg a Youth Knowledge sorozat korábbi kötete egyszerre szólt kutatóknak, szakembereknek és politikai döntéshozóknak, a mostani kiadvány elsősorban a kutatásra összpontosít, valamint a kutatás és a gyakorlat közti kapcsolatra - nem véletlenül, a szerzők többsége maga is kutató szakember.

A kiadvány az ifjúsági mobilitásban részt vevők (a számos országból érkező

A $\mathrm{z}$ összes program leírása megtalálható a következő honlapon: http://www.eplusifjusag.hu/hu/ applicants/guidelines/

2 https://www.researchyouth.eu/results-erasmusyouth-in-action/ szociálpszichológus, politológus, szociológus, projektkoordinátor és -értékelö, tanártovábbképzéssel, módszertani fejlesztésekkel, inkluzivitással foglalkozó szakember, professzor, kutató, illetve diák) tapasztalatait mutatja be, többségében empirikus kutatási analízissel. A 32 szerző között megjelenik egy diszlexiás fiatalokat tömörítő máltai szervezet patrónusa, és maguk a hátrányos helyzetű fiatalok is írnak saját élményeikről. Magyarországi szerző is akad, ő Fazekas Ágnes Sarolta, az ELTE TáTK PhD-hallgatója, aki emellett egy nemzetközi oktatással foglalkozó szervezet (EAIE - European Association for International Education) irányító testületének tagja, illetve külsős tanácsadója a fogyatékkal élők Erasmus+ felsőoktatási munkacsoportjának. Fazekas az általa koordinált, ún. Exchange Ability projekten keresztül mutatja be az inkluzív gyakorlatot (7, fejezet).

A kötet, amely a hátrányos helyzetü fiatalok inkluzivitására, a mobilitási programokba való bevonásuk lehetőségeire fókuszál a nem formális oktatás kontextusában, két egymással összefüggő kérdést tárgyal: hogyan lehet a tanulói mobilitásokat hátrányos helyzetü, kirekesztett emberek számára eszközként és lehetőségként alkalmazni inkluzivitásuk elősegítésére; illetve hogyan válhat az inkluzivitás a tanulói mobilitási projektek és kezdeményezések lényegi elemévé?

Hátrányos helyzetűnek azokat a fiatalokat tekintik, akik „kevesebb lehetőséggel rendelkeznek" (young people with fewer opportunities). Mivel a "kevesebb” vagy „kicsit több mint kevesebb” közti határvonalat igen nehéz meghúzni, így a szerkesztők a határvonalat nem rögzített falnak tekintik, sokkal inkább egy változékony, jobb élethez segítő „ugródeszkának”.

A szerzők a tanulói mobilitások aspektusait kutatva hozzájárulnak a jó gyakorlatok megosztásához is. Ezen belül kiemel- 
ten kezelik mindazokat a megoldásokat, amelyek segítik a hátrányos helyzetü fiatalok motiválását és toborzását a programba, mivel a kutatási eredmények szerint ez jelenti a legnehezebb kihívást.

Hiánypótló a kötet a szerkesztők által választott fókusz (inkluzivitás, tanulási mobilitások révén) miatt, és mert jelenleg a mobilitások iránti növekvő érdeklődés ellenére sem állnak rendelkezésre olyan longitudinális kutatások, amelyek az ifjúsági tanulási mobilitás során szerzett tanulási eredményeket, tapasztalatokat elemzik. Az Európai Unió Tanácsának állásfoglalását az ifjúságpolitika terén folytatott európai együttmüködés keretéről (a 2019 és 2027 közötti időszakra szóló uniós ifjúsági stratégiát) a tagok 2018 novemberében elfogadták - ez a fiatalokkal kapcsolatos valamennyi politikában és tevékenységben már kötelező elemként írja elő az egyenlő hozzáférés és diszkriminációmentesség biztosítását az inkluzivitással együtt, alkalmazva a „semmit rólunk nélkülünk" elvet is a részvételről szóló irányelvben.

Az olvasók számára különösen hasznos lehet - és segíti a célirányos elmélyülést is -, hogy az elméleti részt követő írások elején a szerkesztőbizottság rövid bevezetőben összefoglalást ad az egyes cikkek főbb pontjairól és a kötet általános témájához való viszonyáról.

Tanulási mobilitáson a kötetben olyan határokon átívelö, oktatási célzattal, tudatosan szervezett fizikai mobilitást értenek, amely egy meghatározott idön belül történik, önkéntes részvétellel a nem formális oktatási szférában. Így például a migráció bármennyire is égető problémakör és mobilitási tevékenység, mivel nem oktatási célzattal történik, nem tartozik a vizsgált témák közé, így nem került a kötetbe.
Kristensen (2004, 2015) modellje szerint a sikeres, fejlődést hozó tanulási mobilitás létrejöttéhez a következő négy alapvető feltétel egyidejű megléte szükséges: 1. elmerülés (immersion) egy új kultúrában, amely nem steril, hanem valós közeg; 2. felelősségvállalás (responsibilisation): a résztvevők tevékenyen keresik a megoldásokat az általuk vállalható szintü problémákra; 3. relativizálás (relativation): a feladatok, kérdések a résztvevők számára relevánsak, észrevehetők és egyben megvitathatók; 4. perspektivitás (perspectivation): az egész folyamat elött, alatt és után biztosított a folyamatos visszacsatolás és támogatás. A minőségi eredmények eléréséhez figyelembe kell venni, hogy a tanulási folyamatok túlnyúlnak a külföldi tartózkodás időtartamán, fontos megtervezni a külföldi út előtti és utáni időt is, minden fázisban biztosítva a pedagógiai támogatást és egy bizonyos intenzitású és időtartamú tapasztalatszerzés lehetőségét. Ha mindez kiegészül az inkluzivitással, a kevesebb lehetőséggel rendelkező diákok utaztatásával, akkor különösen hangsúlyossá válik a pedagógiai támogatás megléte már az előkészítő szakasztól kezdődően, a kint tartózkodás alatt végig és minden egyes tájékoztatás során, hogy a részvétel számukra valós lehetőséggé válhasson. Megerösitésre kell helyezni a hangsúlyt, és nem a különbségek felszámolására. A kötet egyik fő célja, hogy a tanulási mobilitás ezen fiatalok társadalmi befogadásának egyik eszközévé váljék.

\footnotetext{
S. Kristensen: Learning by Leaving: Placements Abroad As a Pedagogical Tool in the Context of Vocational Education and Training in Europe. Aarhus, 2004. University of Aarhus. - S. KrisTENSEN: Measuring the Un-Measurable: Evaluating Youth Mobility As a Pedagogical Tool for Intercultural Learning. In: A. Kuppers \& C. Bozdag (eds) Doing Diversity in Education Through Multilingualism, Media and Mobility. Istanbul, 2015. Istanbul Policy Center. pp. 31-33.
} 
De kik is tartoznak a kevesebb lebetöséggel rendelkezö fiatalok csoportjába, és mit jelent a társadalmi befogadás? Általános megközelítés szerint olyan fiatalok, akik bizonyos társadalmi, gazdasági, oktatási, kulturális, földrajzi, egészségügyi vagy fogyatékossággal összefüggő tényezők alapján sérülékenyeknek tekinthetők. ${ }^{4}$ A Social Inclusion Monitor Europe 5 szerint a társadalmi integráció hat dimenziót foglal magában: 1 . szegénység megelözése; 2 . egyenlő oktatás; 3. munkaerőpiaci hozzáférés; 4. egészségügy; 5. társadalmi kohézió és diszkriminációmentesség; 6. nemzedékek közötti igazságosság. E hat dimenzió nem független egymástól, hanem folyamatosan kapcsolatban van és hat egymásra. Az igazán lényeges szempontok: a kirekesztés mértéke (egy vagy több dimenzióban), az egyes dimenziók közötti kumulatív kölcsönhatások, a társadalmi kizárások megelőzéséhez és leküzdéséhez szükséges készségek és önbizalom. A társadalmi befogadást elősegítő tanulási mobilitások pozitív hatásait élvezik a jobb helyzetben lévő fiatalok is, de a kevesebb lehetőséggel élők számára ez egy sokkal sürgetőbb és meghatározóbb lehetőség, mivel „számukra a társadalmi befogadás magában foglalja különböző akadályok előzetes megszüntetésének szükségességét, még mielőtt társadalmi jogaikat a társadalom teljes tagjaként megszerezhetnék". 6

A társadalmi befogadás folyamatos történés mindenki életében, és így bármivel is próbáljuk elérni (pl. tanulási mobilitás

4 További részletek olvashatók a Youth in Action program útmutatójában az alábbi linken: www. salto-youth.net/tools/otlas-partner-finding/ help/young-people-with-feweropportunities/.

5 Lásd a hivatalos oldalt: https://www.socialinclusion-monitor.eu/.

6 S. Kovacheva (é. n.): EU-CoE Youth Partnership Policy Sheet: Social Inclusion. https://pjp-eu.coe. int/documents/1017981/1668219/Social+ inclusion+by+Siyka+Kovacheva/. [Letöltve: 2019. 02. 12.] vagy más tevékenységek révén), az sosem lehet egyszeri tevékenység. Ugyanannak a csoportnak más-más tagja számára különbözőképpen közelíthető meg (például tudatossággal, megelőzéssel, közvetlen ráhatással stb.). Fontos hangsúlyozni, hogy a társadalmi befogadás és a társadalmi sokszínűség egyszerre vége, célja és ezzel egyidejüleg eszköze a tevékenységeknek, és különböző emberek közötti kölcsönhatások eredményeként kell, hogy megszülessen.

Jelen kötet a társadalmi befogadást elösegítő tanulási mobilitásokra koncentrál a nem formális oktatási szférában, amely föként az ifjúsági munka keretében történik. $\mathrm{Az}$ iffúsági munka mára külön szektorrá fejlődött, identitása a különböző európai és nemzeti szintü kezdeményezések révén fokozatosan erősödik. Számos formában létezhet, de mindegyik középpontjában a fiatalok egyéni és csoportos fejlődésének támogatása áll. $\mathrm{A} z$ ifjúságpolitika terén folytatott európai együttmüködés megújított keretéröl (2009. november 27.) szóló tanácsi állásfoglalásban az ifúsági munka egy tág kifejezés, amely a fiatalokkal, körükben és/vagy számukra végzett társadalmi, kulturális, sport, oktatási, politikai tevékenységeket, szolgáltatásokat egyaránt magában foglalhatja. További jellemzői, hogy iskolán kívül, nem formális tanulási környezetben is történhet önkéntes részvétel során. Érdekesség, hogy az európai dokumentumokban az ifúsági munka és a nem formális tanulás fogalma szinte felcserélhető egymással. Lynne Chisholm ${ }^{7}$ szerint a nem formális tanulás olyan céltudatos, de önkéntes tanulás, amely sokféle környezetben és helyzetben zajlik, és amely során a tanítás/képzés vagy a tanu-

L. Chisholm: Bridges for Recognition. [Proceedings of SALTO Bridges for Recognition: Promoting Recognition of Youth Work across Europe, Leuven, 19-23 January 2005]. Brussels, 2005. SALTO-YOUTH. p. 49. 
lás nem feltétlenül az egyedüli vagy a fó tevékenység. Szakmai mentorok vagy önkéntesek is segíthetik a folyamatokat, és a tanulási eredmények értékelése jellemzően nem a hagyományos keretek között történik. A nem formális tanulás meghatározása külön hangsúlyozza az önkéntes részvételt, és azt is, hogy a folyamatot egyszerre támogatják és vezetik fiatal munkavállalók és vezetők. Európában jellemző, hogy a formális, nem formális és informális tanulás közötti határok elmosódnak (lásd az 5. és 11. fejezetben bemutatott példákat). Mivel mind az ifjúsági munka, mind a nem formális tanulás során irányított tanulás történik, így fontos a fiatalok fejlödését és inklúzióját lehetővé tevő módszertan és megközelítés, amivel számos írás foglalkozik a kötetben. Filip Coussée (2016: $85),{ }^{8}$ és több európai dokumentum (pl. a 2015-ös Declaration of the 2nd European Youth Work Convention ${ }^{9}$ ) ezt kiegészíti még egy fontos szemponttal: az ifjúsági munka bár számon tartja, de semmiképpen sem szabad, hogy a végeredményre, a tanulási eredményekre koncentráljon, hanem csakis magára a tanulási folyamatra és a tanulók igényeire, szükségleteire. A mérés-értékelések, indikátorok előtérbe kerülésével azonban a legtöbb ifjúsági munka ma mégis föleg az eredményekre összpontosít - nem kivételek ez alól a jelen kötet írásai sem.

A társadalmi befogadás, tanulási mobilitás, ifjúsági munka, valamint a nem formális oktatás mint alapvető fogalmak tisztázását követő három fö rész magában

8 F. Coussée: Introduction to Part IV - Half Boy and Half Man. In: L. Siurala, F. Coussée, L. Suurpaa \& H. Williamson (eds) The History of Youth Work in Europe. Vol. 5. [Youth Knowledge Book, 19]. Strasbourg, 2016. Council of Europe. p. 85 .

9 https://pjp-eu.coe.int/documents/1017981/ 8529155/The+2nd+European+Youth+Work+ Declaration_FINAL.pdf [Letöltve: 2019. 02. 10.] foglalja a tanulási mobilitási folyamat szakaszainak és dimenzióinak teljes terjedelmét: hozzáférés, elérés és célok után a folyamatok, stratégiák és gyakorlatok bemutatása következik, amit végül a hatások, eredmények és nyomon követések összefoglalása zár.

A Hozzáférés, elérés és célok c. fejezetben szereplő írások a tanulási mobilitás és a társadalmi befogadás hátterét és összefüggéseit tárják fel főként diszkurzív megközelítésben, valamint azt vizsgálják, hogy mennyire hatékonyan és széles körűen, a különböző célcsoportok számára egyenlő hozzáférést biztosítva terjesztettek a tanulási mobilitási lehetőségek. A Folyamatok, stratégiák és gyakorlatok c. fejezet konkrét projekteket mutat be, a példákon keresztül megoldási módozatokat felvázolva, valamint kiemelve a föbb kihívásokat, lehetöségeket, amelyek menet közben a megvalósítás alatt merültek fel. Az értékeléseket adó utolsó nagyobb, Hatások, eredmények és nyomon követések címủ fejezet végül a nemzeti és európai szinteken elért elöre tervezett és véletlenül elért eredményeket mutatja be.

A kötet föbb konklúziója, hogy a tanulási mobilitás támogatására és az inkluzivitásra irányuló valódi erőfeszítéseknek számolniuk kell a következményekkel is, ezért a programok szerkezetét, tartalmát és a szükséges pedagógiai támogatásokat a változatos célcsoport igényeihez mérten kell átgondolni, újakat bevezetni vagy a régieket finomítani. A cél nem maga az utazás lebonyolítása kell, hogy legyen, hanem új készségek, képességek és kompetenciák megszerzése (pl. használható nyelvtudás, külföldi tapasztalat, kommunikációs, szociális készségek), amelyek segítik a hazatérők személyes és szociális fejlődését, valamint előmozdítják aktív szerepvállalásukat a társadalom életében, és ennek következtében javítják foglalkoztatási kilátásaikat. Ehhez a tanulási 
célok összhangjának megteremtése szükséges a célcsoporttal és az alkalmazott módszertannal - egyfajta finomhangolás jó gyakorlatok adaptálása révén, amihez fontos segédlet lehet a jelen kötet.

A cikk a Creative Commons Attribution 4.0 International License (https://creativecommons.org/licenses/ by/4.0/) feltételei szerint publikált Open Access közlemény, melynek szellemében a cikk bármilyen médiumban szabadon felhasználható, megosztható és újraközölhető, feltéve, hogy az eredeti szerző és a közlés helye, illetve a CC License linkje és az esetlegesen végrehajtott módosítások feltüntetésre kerülnek. (SID_1) 